\title{
STEADY AND TRANSIENT THERMAL STATE OF TURBINE DISK ESTIMATION FOR LIFE TIME MONITORING
}

\author{
Yevhen Martseniuk \\ Department of Aircraft Engine Design, Faculty of Aviation Engines, National M.E. Zhukovsky \\ Aerospace University "Kharkiv Aviation Institute", Chkalova str., build. 17, Ukraine \\ y.martseniuk@khai.edu•ORCID:0000-0002-4992-7603
}

\begin{abstract}
In connection with increasing intensification of the working process in a gas turbine engine and increasing requirements for economy, the problem of defining and monitoring the main parts lifetime is becoming more vital. Modern algorithms of the monitoring systems are based on taking into account the levels of part temperature and total equivalent stress throughout the flight cycle. Thermal and stressstrain states of the critical zones of the main parts are determined on the basis of information received from the sensors installed in the engine gas path. Turbine disks are located in the internal cavities of the engine and are cooled by air from the compressor. However, in some designs, the disk cavity can be separated from the place of cooling air bleed by several stages of non-contact labyrinth seals, which will lead to some delay in changing the parameters of the cooling air flow when changing the engine operating mode. It has been observed that if this situation is not taken into account, it can lead to significant errors (more than 40\%) in determining the lifetime for the peripheral zone of the disk. At the same time, this error is minimal for the hub and the middle zone of the disk, and the existing monitoring algorithms can be used.
\end{abstract}

Keywords: lifetime, monitoring, thermal-stress state, model.

\section{INTRODUCTION}

It is a very challenging problem to consider the life of all and every part, and of course it will make no sense as the life of the whole engine is determined by the set of parts called "main parts", whose damage cannot be localized inside the engine.

Life of the main engine parts is set based on the generic life cycle and validated experimentally. The most considerable group of tests are known as equivalent-cyclic tests. The flight cycles observed in the maintenance can be very different from the generic flight cycle. This is a vital issue as the damage in the real flight cycle is very different from the generic one. While solving the highlighted problem the engineers met the problem of engine condition monitoring, which includes many aspects, for example, life depletion monitoring from the flight data.

Monitoring systems of the engine lifetime are an effective method of implementing condition-based maintenance of a gas turbine engine [1-2]. Such systems help to fully use the assigned resource of the engine as well as increase its reliability. 
Different approaches were developed for this reason, like the ones based on finite element analysis [3], statistical methods [4], and neural networks [5]. However, in order to improve the lifetime prediction accuracy, it is necessary to perform estimation of the lifetime in real time using actual conditions. But there are two significant limitations for useing noted the above approaches in online prediction. The main problem lies in requiring a large amount of computing resources. Moreover, none of the cited approaches take into consideration the existing engine-to-engine difference and performance degradation.

\section{KNOWN CONCEPTS OF LIFETIME MONITORING}

There are a few different monitoring methods available nowadays in engineering practice [6]. The simplest method is called life counter. According to it, the operational range is devided into segments with their weights. The weight is proportional to a relative damage intensity of the segment. Next, the flight time is clustered between the segments, and finally, the total relative damage is evaluated as a weighted sum of the clustered times. The only advantage of this method is its simplicity; however, the precision of the depleted life evaluation is very low.

Contrary to the first method, the most advanced modern methods deal with the life monitoring of each main part. The milestones of this method are:

- Analysis of temperature and stress alternation from the field data.

- Evaluation of damage with further depleted life calculation.

Pic. 1 illustrates the principal difference between noted concepts of lifetime monitoring.

In order to take the best practices from well-known monitoring systems, the recently developed method must meet the following requirements and have the following features:

- The life monitoring system must have the same fracture, thermal and stress models to the system of life setting up.

- The system should be able to consider loading as an operational mode dependent parameter. This can be achieved by the use of the static and dynamic similarity of the loading at different operational modes.

- The processing time should be short, because no one is interested in good monitoring systems that work for hours or days. This can be achieved by deriving models used in the monitoring system from the finite element models and verifing them by means of identification. Precision loss in this case is negligibly small.

The block diagram of the analysis flow is presented in Pic. 2. The life monitoring starts from the evaluation of the parameters that are not directly measured by the sensors but are needed for the further thermal boundary conditions calculation. As soon as the boundary conditions are known, a thermal analysis is conducted. Its goal is to measure the temperature of the critical points followed by the thermal-stress analysis whose output is the mechanical stress. The sum of thermal and mechanical stresses corresponds to the total stress. Next, the variation of equivalent stress and temperature from the flight data help to segment the flight into some stages of stationary loading, and the loading cycles for evaluating the damages caused by the creep and low-cycle fatigue. At the last stage of the algorithm, the evaluated damages are compared to their norms from the regulations and the depleted life is obtained in hours and cycles. 
The following models are involved in the lifetime estimation process:

1) Model of the engine operation to calculate the boundary conditions and loading parameters.

2) Steady state thermal and stress-strain models.

3) Dynamic thermal and stress-strain model.

4) Model of equivalent stress.

5) Creep model.

6) Low-cycle fatigue model.

7) Model for damage summing up.

8) Model for damage summing up at a complex loading.

A large number of works are devoted to the study of methods for modelling thermal state and described in [6].

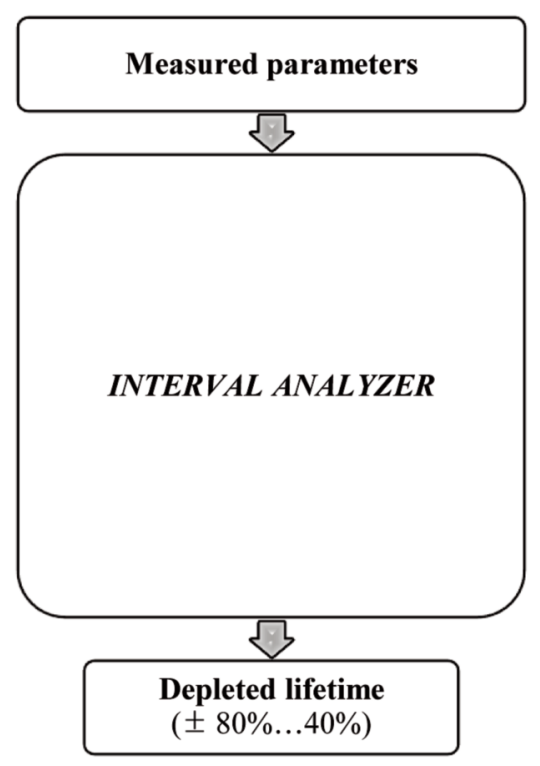

a)

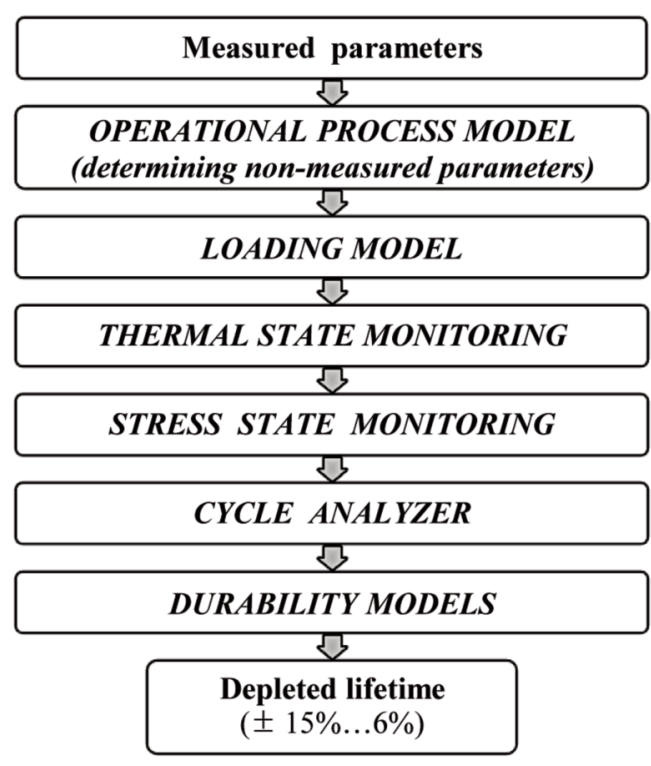

b)

Pic. 1. Block diagrams of lifetime monitoring concepts: a) life counters; b) lifetime monitoring system.

Monitoring models of the steady thermal state are intended for continuous monitoring of temperature in critical points of the main engine parts in the steady-state modes.

Based on the features of gas turbine engine design and air bleeds process for the needs of the cooling system, O. Oleynik suggested the similarity of the heat transfer boundary conditions at different engine operating modes. According to [7] the temperature in critical point of the part can be found from the equation:

$$
\Theta=\frac{t-T_{1}}{T_{2}-T_{1}},
$$

where $\Theta$ - dimensionless coefficient of cooling efficiency, $t$ - temperature in critical (controlled) point, $T_{2}, T_{1}$ - gas path temperatures, that define a thermal state of the part, so called "heating» and "cooling» temperature. 


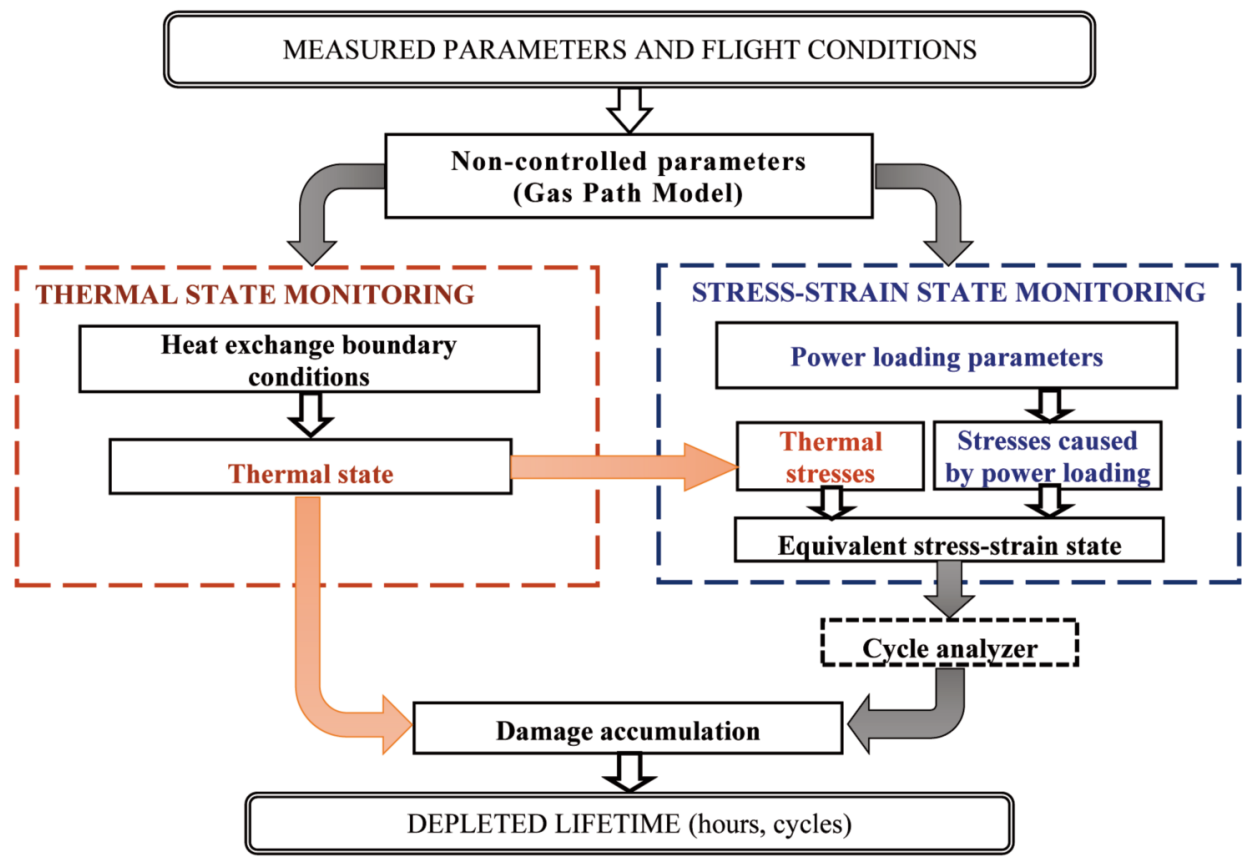

Pic. 2. Data processing for life time monitoring.

In a common case the parameter $\Theta$ is an unknown function of thermal loading at different engine operating modes. From [7] it is seen, that to set $\Theta$ in correspondence with parameters of the engine operation, it is better to use the relation:

$$
\Theta=f\left(k_{\alpha} / k_{\lambda}\right)
$$

where:

$k_{\alpha}=\alpha / \alpha_{\text {ref }}-$ the heat transfer similarity coefficient is equal to the ratio between the local heat transfer coefficient $\alpha$ at the arbitrary mode and the reference mode $\alpha_{r e f}$,

$k_{\lambda}=\lambda(\tilde{t}) / \lambda\left(\tilde{t}_{\text {ref }}\right)$ - parameter characterizing the difference in the thermal conductivity of the material from its values in the reference mode,

$\tilde{t}=T_{1}+\tilde{\Theta}\left(T_{2}-T_{1}\right)$ - the characteristic temperature of the part to account for changes in thermal conductivity;

$\tilde{\Theta}=\frac{\tilde{t}_{r e f}-T_{1 . r e f}}{T_{2 . r e f}-T_{1 . r e f}}-$ relative value of the characteristic temperature, constant for all operating mode;

$\tilde{t}_{r e f}$ - the characteristic temperature at the reference mode defined as the ambient temperature averaged over heat transfer:

$$
\tilde{t}_{r e f}=\left(\frac{\int_{A} \alpha T_{a v} d A}{\int_{A} \alpha d A}\right)
$$

where: $d A$ - area of a surface segment, $T_{a v}$ - average ambient temperature at the area $d A$; 
or as the limit:

$$
\tilde{t}_{r e f}=\lim _{k_{\alpha} \rightarrow 0} t_{r e f} .
$$

Algorithms for calculating temperature in an unsteady mode are based on the representation of it by the sum of temperature increments in transients caused by changes in control temperature at previous times [8]:

$$
t_{i}=t_{0}+\sum_{k=0}^{i} \Pi_{v_{k}}\left(t_{s t_{k}}-t_{s t_{k-1}}\right)
$$

where:

$\Pi_{v}-$ transient performance of the temperature in the critical point of the part,

$v$ - model time when creating the transient performance,

$t_{s t_{k}}=t_{s t}\left(t_{u_{k}}\right)$-steady-state value of the critical point temperature (function of control temperature $t_{u}$ ), $i, k-$ moments of time.

In the case the system parameters are varied with time: $p=p(\tau)$, the unsteady transient performance is used:

$$
t_{i}=t_{0}+\sum_{k=0}^{i} \Pi_{v_{k}}\left(p\left(v+\tau_{k}\right)\right)\left(t_{s t_{k}}-t_{s t_{k-1}}\right) .
$$

Thus, the temperature of a fluid that is in contact with the $i^{\text {th }}$ surface depends on the reference fluid temperature and temperature similarity coefficient $k_{t}$. Finally, to evaluate the heat exchange boundary conditions at the arbitrary operational mode, the local heat transfer coefficients at the reference mode $\alpha_{r e f}$ and the heat transfer similarity coefficient $k_{\alpha}$ must be set.

\section{EFFECT OF THE FLOW DYNAMICS IN INNER CAVITIES ON THE LIFETIME ESTIMATION ACCURACY}

While developing the algorithm, one will meet numerous problems dealing with the accuracy of each stage. One of them is as follows: the turbine disk is a massive part from the engine hot zone, whose thermal state has huge effect on varied levels of stress. The known life monitoring algorithms link the heat exchange boundary conditions on part surfaces with flow parameters in the engine gas path. The typical scheme of thermal and power loading of HPT disk is shown in Pic.3. The 3d kind thermal boundary conditions (BC) act on the all side surfaces of the disk and represent heat exchange with cooling air $\left(\alpha_{2} ; T_{2} \ldots \alpha_{12} ; T_{12}\right)$. The heat exchange between rotor blades and disk is simulated with equivalent convective $\mathrm{BC}\left(\alpha_{1} ; T_{1}\right)$. Power loading is represented by angular velocity $\omega$ and tensile radial stresses caused by mass of rotor blades $\sigma_{B L}$.

However, the disk is located in an inner cavity and is separated from the main gas flow by numerous seals between the rotor and the stator. This can lead to some delay in the time of changing the $\mathrm{BC}$ that act from the cooling air side.

To evaluate the effect of this delay on the thermal-stress state of the disk, a number of transient analysis were performed. The nominal thermal-stress state of the disk is defined without any delay between changing in "hot" (from the rotor blade side) and "cold" (from the cooling air side) BC. Then, cases with delays in 30, 60 and 180 seconds were simulated. Pic. 4 shows the varying of stress (a) and temperature (b) in the disk rim. The graphs illustrate ratio of current parameter value to its maximum level from nominal case (without delay). 


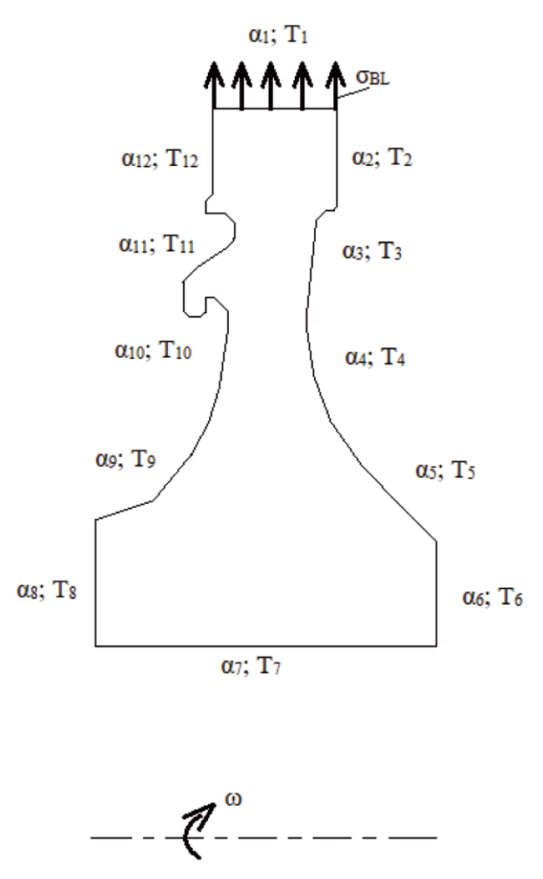

Pic. 3. Scheme of HPT disk thermal and power loading.

Tab. 1 consists the stress to stress ratio and corresponding temperature to temperature ratio for different delay times in critical zones of the turbine disk, which are slots in the rim for installing blade, holes for screwing disk with shaft and inner surface of central hole in the hub.

As it is seen from Tab. 1, the significant influence on thermal-stress state of the disk appears in periphery critical zone, which is hotter and closer to the gas path of the engine. This happens because of lack of cooling when engine operating mode is increased.

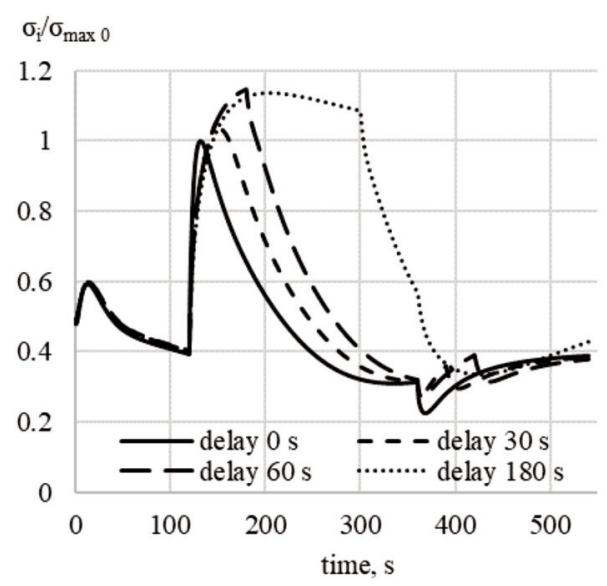

a)

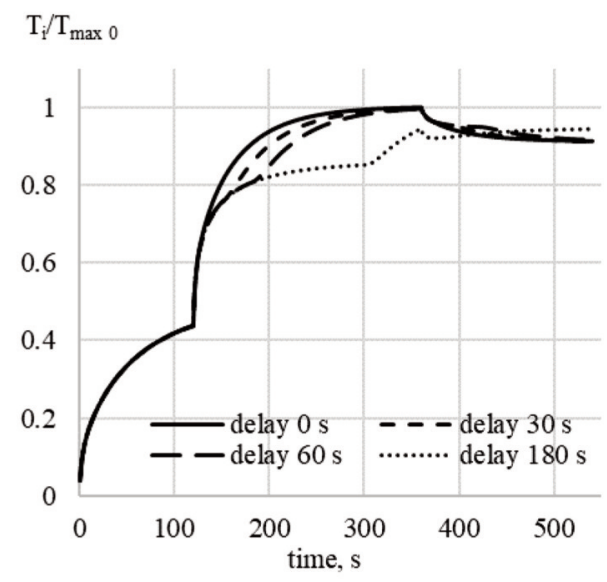

b)

Pic. 4. Relative change in stress (a) and temperature (b) in the disk rim for different delay time. 
Table 1. Influence of BC delay on maximum level of stress in critical zones of the turbine disk.

\begin{tabular}{|c|c|c|c|c|c|}
\hline \multirow{2}{*}{ Relative parameter } & \multirow{2}{*}{ Zone } & \multicolumn{4}{|c|}{ Delay, s } \\
\hline & & $\mathbf{0}$ & 30 & 60 & 180 \\
\hline$\sigma_{\max } / \sigma_{\max 0}$ & \multirow{2}{*}{ Disk rim } & 1.0 & 1.065 & 1.148 & 1.136 \\
\hline $\mathbf{T}\left(\sigma_{\max }\right) / \mathbf{T}\left(\sigma_{\max 0}\right)$ & & 0.694 & 0.756 & 0.805 & 0.825 \\
\hline$\sigma_{\max } / \sigma_{\max 0}$ & \multirow{2}{*}{ Section of holes for screws placement } & 1.0 & 0.998 & 0.999 & 1.062 \\
\hline $\mathbf{T}\left(\sigma_{\max }\right) / \mathbf{T}\left(\sigma_{\max 0}\right)$ & & 0.972 & 0.971 & 0.973 & 0.369 \\
\hline$\sigma_{\max } / \sigma_{\max 0}$ & \multirow{2}{*}{ Disk hub } & 1.0 & 0.997 & 0.989 & 0.957 \\
\hline $\mathrm{T}\left(\sigma_{\max } \mathrm{i}\right) / \mathrm{T}\left(\sigma_{\max 0}\right)$ & & 0.662 & 0.671 & 0.683 & 0.699 \\
\hline
\end{tabular}

It is known that damage of the turbine disk is caused primary by low cycle fatigue [9], so for evaluating an error in lifetime estimation the Manson's equation [10] was used:

$$
\Delta \varepsilon=\frac{1}{2}\left(\ln \frac{1}{1-\psi}\right)^{0.6} N^{-0.6}+1.75 \frac{\sigma_{u}-\sigma_{m}}{E} N^{-0.12}
$$

where $\Delta \varepsilon$ - amplitude range, $\psi$ - contraction ratio, $\sigma_{u}$ - ultimate strength, $\sigma_{m}-$ mean stress in cyclic loading, $E$ - elasticity modulus, $N$ - number of cycles to fracture.

Tab. 2 presents the result of lifetime estimation in relative form $N_{i} / N_{0}$, where $N_{0}$ - number of cycles to fracture with simultaneous changing BC at all surfaces, $N_{i}$ - number of cycles to fracture corresponds to noted delays in $\mathrm{BC}$ changing.

Tab. 2. Influence of BC delay on maximum level of stress in critical zones of the turbine disk.

\begin{tabular}{|l|l|l|l|l|}
\hline \multirow{2}{*}{ Cycles to fracture ratio } & \multirow{2}{*}{ Zone } & \multicolumn{3}{c|}{ Delay, $\mathbf{s}$} \\
\cline { 3 - 5 } & & $\mathbf{0}$ & $\mathbf{3 0}$ & $\mathbf{6 0}$ \\
\hline $\mathbf{N}_{\mathrm{i}} / \mathbf{N}_{\mathbf{0}}$ & Disk rim & 1.0 & 0.637 & 0.348 \\
\hline $\mathbf{N}_{\mathrm{i}} / \mathbf{N}_{\mathbf{0}}$ & Section of holes for screws placement & 1.0 & 1.009 & 1.004 \\
\hline $\mathbf{N}_{\mathrm{i}} / \mathbf{N}_{\mathbf{0}}$ & Disk hub & 1.0 & 1.020 & 1.075 \\
\hline
\end{tabular}

\section{CONCLUSIONS}

The analysis shows that if the delay in changing the heat transfer boundary conditions is not taken into account it can lead to significant error in the lifetime estimation when the critical zone is located in the slot for blade installation. So with a delay of 30 seconds, the error can reach $40 \%$ or more. This fact can be taken into account when creating monitoring models of unsteady temperatures (5) by making an appropriate correction. To make such an adjustment, a number of additional analysis is required to study the dynamics of changes in the airflow parameters in the internal cavities of the engine.

If the critical zone is located on the hub or in the area of the screw holes, such a correction is not required. 


\section{REFERENCES}

[1] Jin, H., Lowden, P. and Pistor, R., 2008,"Remaining Life Assessment of Power Turbine Disks." Proceedings of the ASME Turbo Expo 2008: Power for Land, Sea, and Air. Volume 7: Education; Industrial and Cogeneration; Marine; Oil and Gas Applications. ASME, pp. 655-660. 10.1115/GT2008-51010.

[2] Dowson, P. and Dowson, D., 2011, "Remaining Life Assessment Technology Applied to Steam Turbines and Hot Gas Expanders." Proceedings of the ASME 2011 Turbo Expo: Turbine Technical Conference and Exposition. Volume 6: Structures and Dynamics, Parts A and B. ASME, pp. 47-61. 10.1115/GT2011-45324.

[3] Jeromin, A., Eichler, C., Noll, B. and Aigner, M., 2008, "Full 3D Conjugate Heat Transfer Simulation and Heat Transfer Coefficient Prediction for the Effusion-Cooled Wall of a Gas Turbine Combustor." Proceedings of the ASME Turbo Expo 2008: Power for Land, Sea, and Air. Volume 4: Heat Transfer, Parts A and B. ASME, pp. 1747-1756. 10.1115/GT2008-50422.

[4] Nozhnitski, Y. A., Lokshtanov, E. A., Dolgopolov, I. N., Shashurin, G. V., Volkov, M. E., Tsykunov, N. V., and Ganelin, I. I. 2006, "Probabilistic Prediction of Aviation Engine Critical Parts Lifetime." Proceedings of the ASME Turbo Expo 2006: Power for Land, Sea, and Air. Volume 5: Marine; Microturbines and Small Turbomachinery; Oil and Gas Applications; Structures and Dynamics, Parts A and B. ASME, pp. 1025-1034. 10.1115/GT2006-91350.

[5] Palme', T., Breuhaus, P., Assadi, M., Klein, A., and Kim, M., 2011, "Early Warning of Gas Turbine Failure by Nonlinear Feature Extraction Using an Auto-Associative Neural Network Approach." Proceedings of the ASME 2011 Turbo Expo: Turbine Technical Conference and Exposition. Volume 3: Controls, Diagnostics and Instrumentation; Education; Electric Power; Microturbines and Small Turbomachinery; Solar Brayton and Rankine Cycle. ASME, pp. 293-304. 10.1115/GT201145991.

[6] Oleynik, A.V., 2006, "The concept and methods of lifetime depletion monitoring of gas turbine air-engine based on a dynamic identification of thermal and stress condition of main details", Sc.D. thesis, National Aerospace Univ., Kharkov, Ukraine.

[7] Oleynik, A.V. and Shimanovskaya, N.A., 2003, "The choice of algorithms for monitoring the temperature of parts in steady conditions to account for the lifetime depletion of a gas turbine engine", Aerospace Technics and Technology, 40(5), pp. 105-108.

[8] Yepifanov, S.V., Zelenskyi, R.L. and Loboda, I.I., 2015, "Modeling the GTE under its dynamic heating conditions", Engineering for gas turbines and power (March 2015), 137(3), pp. 0315061-031506-10.

[9] Krykonov, D., 2005, Handbook of Engine Lifetime Prediction. Kharkiv, Ukraine: National Aerospace University of Ukraine, p. 67.

[10] Kolotnikov, M., 2003, Limit states of the parts and the lifetime prediction of gas turbine engines under multicomponent loading conditions. Rybinsk: RGATA, p. 136. 


\title{
STAŁE I PRZEJŚCIOWE OSZACOWANIE STANU TERMICZNEGO TARCZYTURBINYW CELU MONITOROWANIA JEJ ŻYWOTNOŚCI
}

\begin{abstract}
Abstrakt
W związku z coraz większą intensyfikacją procesu pracy w silniku turbiny gazowej i rosnącymi wymaganiami ekonomicznymi, coraz bardziej zaostrza się problem definiowania i monitorowania żywotności głównych części. Nowoczesne algorytmy systemów monitorowania opierają się na uwzględnianiu poziomów temperatury części i całkowitego równoważnego obciążenia w całym cyklu lotu. Stany termiczne i naprężeniowo-odkształceniowe stref krytycznych części głównych określane są na podstawie informacji otrzymywanych z czujników zainstalowanych w torze gazowym silnika. Tarcze turbinowe umieszczone są w wewnętrznych wnękach silnika i są chłodzone powietrzem ze sprężarki. Jednak w niektórych konstrukcjach wnęka tarczowa może być oddzielona od miejsca upustu powietrza chłodzącego kilkoma stopniami bezdotykowych uszczelnień labiryntowych, co spowoduje pewne opóźnienie zmiany parametrów przepływu powietrza chłodzącego przy zmianie trybu pracy silnika. Wykazano, że jeśli sytuacja ta nie będzie brana pod uwagę, może to prowadzić do znacznych błędów (ponad 40\%) w określeniu okresu eksploatacji dla strefy peryferyjnej tarczy. Jednocześnie błąd ten jest minimalny dla koncentratora i strefy środkowej dysku, a istniejące algorytmy monitorujące mogą być stosowane.
\end{abstract}

Słowa kluczowe: żywotność, monitoring, stan naprężenia termicznego, model. 